\title{
PEMBELAJARAN BAHASA ARAB DI MADRASAH ALIYAH DALAM PERSPEKTIF KURIKULUM 2013
}

(Sebuah Tinjauan Yuridis)

\author{
Miftahur Rohman \\ Sekolah Tinggi Ilmu Tarbiyah (STIT) Bustanul 'Ulum \\ Jaya Sakti, Anak Tuha, Kabupaten Lampung Tengah, Lampung 34173 \\ e-mail:miftahur1rohman@gmail.com
}

\begin{abstract}
Abstrak
Kurikulum merupakan blue print dan acuan dalam implementasi pembelajaran. Yang berlaku dalam sistem pendidikan di Indonesia saat ini adalah kurikulum 2013 yang merupakan penyempurnaan dari kurikulum sebelumnya. Kurikulum 2013 memiliki seperangkat komponen yang hendaknya diperhatikan dalam penerapannya. Di sisi lain, pembelajaran merupakan bentuk implementasi dari kurikulum tersebut. Oleh karenanya, pembelajaran, termasuk pembelajaran bahasa Arab di Madrasah Aliyah harus mengacu pada landasan yuridis yang berlaku serta memperhatikan komponen-komponen dalam kurikulum 2013 itu sendiri. Dalam hal ini komponen-komponen kurikulum tersebut di antaranya: tujuan pembelajaran, Materi dan sumber belajar, strategi dan metode pembelajaran, dan evaluasi sebagai instrumen penilaian. Komponen-komponen tersebut harus mengacu pada peraturan dan perundang-undangan yang berlaku dan menjadi pijakan implementasi pembelajaran bahasa Arab di madrasah aliyah.
\end{abstract}

Kata Kunci: Pembelajaran Bahasa Arab, Madrasah Aliyah, Kurikulum 2013 


\section{A. Pendahuluan}

Kurikulum merupakan suatu rencana yang memberi pedoman atau pegangan dalam proses kegiatan belajar-mengajar. ${ }^{1}$ Menurut Undang-Undang Nomor 20 Tahun 2003 tentang Sistem Pendidikan Nasional, kurikulum adalah seperangkat rencana dan pengaturan mengenai tujuan, isi, dan bahan pelajaran serta cara yang digunakan sebagai pedoman penyelenggaraan kegiatan pembelajaran untuk mencapai tujuan pendidikan tertentu. ${ }^{2}$ Wayne Ross mendefinisikan kurikulum bukan semata-mata materi pelajaran saja, tetapi juga berupa pengalaman interaksional di mana guru dan siswa terlibat di dalamnya. Dalam pandangan ini, kurikulum hendaknya dirancang dalam mendukung guru untuk dapat mengimplementasikan pembelajaran dengan baik. $^{3}$

Kurikulum 2013 bertujuan untuk mempersiapkan manusia Indonesia agar memiliki kemampuan hidup sebagai pribadi dan warga negara yang beriman, produktif, kreatif, inovatif, dan afektif serta mampu berkontribusi pada kehidupan bermasyarakat, berbangsa, bernegara, dan peradaban dunia. Kurikulum 2013 Mata Pelajaran Pendidikan Agama Islam dan Bahasa Arab di Madrasah dikembangkan dengan landasan filosofis yang memberikan dasar bagi pengembangan seluruh potensi peserta didik menjadi manusia Indonesia berkualitas yang tercantum dalam tujuan pendidikan nasional. Dengan demikian, kurikulum merupakan seperangkat komponen dalam kegiatan pembelajaran mulai dari perencanaan, pelaksanaan, sampai evaluasi dalam kegiatan pembelajaran yang bertujuan untuk mencapai tujuan pendidikan yang tertuang dalam undang-undang.

\footnotetext{
${ }^{1}$ Nana Syaodih, Metode Penelitian Pendidikan, (Bandung: Rosdakarya, 2009), hlm.5

${ }^{2}$ Undang-undang Nomor 20 Tahun 2003 Tentang Sistem Pendidikan Nasional

3 Wayne Ross, The Social Studies Curriculum: Purposes, Problems, and Possibilities, (New York: State University of New York Press, 2008), hlm. 11.
} 


\section{B. Pijakan Kurikulum dalam Implementasi Pembelajaran Bahasa Arab}

Terdapat empat komponen yang harus diperhatikan di dalam kurikulum: 1) tujun, 2) materi, 3) startegi dan model, 4) media, dan 5) evaluasi. Kelima komponen tersebut memiliki keterkaitan yang erat dan tidak bisa dipisahkan. Untuk lebih jelasnya akan diuraikan dalam subbab berikut:

\section{Tujuan Pembelajaran}

Mengingat pentingnya pendidikan bagi manusia, hampir di setiap negara telah mewajibkan para penduduknya untuk mengikuti kegiatan pendidikan. Pendidikan yang dijalankan hendaknya menyesuaikan dengan falsafah negara serta kondisi sosial-politik, ekonomi, dan lingkungan masingmasing. Kendatipun demikian, dalam menentukan tujuan pendidikan pada dasarnya memiliki esensi yang sama. Dalam perspektif pendidikan nasioanl, tujuan pendidikan nasioanal dapat dilihat secara jelas dalam Undang-undang nomor 20 tahun 2003 tentang Sistem Pendidikan Nasional. "Bahwa pendidikan nasional berfungsi mengembangkan kemampuan dan bentuk watak serta peradaan bangsa yang bermartabat dalam rangka mencerdaskan kehidupan bangsa bertujuan untuk berkembangnya potensi peserta didik agar menjadi manusia yang beriman dan bertakwa kepada Tuhan yang Maha Esa, berakhlak mulia, sehat,berilmu, cakap, kreatif, mandiri dan menjadi warga negara yang demokratis serta bertanggung jawab.”

Tujuan-tujuan pendidikan mulai dari pendidikan nasional sampai dengan tujuan mata pelajaran masih bersifat abstrak dan konseptual, Oleh karena itu perlu dioperasionalkan dan dijabarkan lebih lanjut dalam bentuk tujuan pembelajaran, yakni tujuan pendidikan yang lebih operasioanal yang hendak dicapai dari setiap kegiatan pembelajaran dari setiap mata pelajaran. Pada tingkat operasional ini, tujuan pendidikan dirumuskan lebih bersifat spesifik dan lebih menggambarkan tentang "what will the student able to do 
as result of the teaching that he was unable to do before". ${ }^{4}$ Dengan kata lain, tujuan pendidikan tingkat operasioanal ini lebih menggambarkan perubahan perilaku spesifik apa yang hendak dicapai peserta didik melalui proses pembelajaran.

Berdasarkan Permendikbud nomor 59 tahun 2014 dapat dilihat bahwa kurikulum 2013 bertujuan untuk untuk mempersiapkan manusia Indonesia agar memiliki kemampuan hidup sebagai pribadi dan warga negara yang beriman, produktif, kreatif, inovatif, dan afektif serta mampu berkontribusi pada kehidupan bermasyarakat, berbangsa, bernegara, dan peradaban dunia. Di era persaingan bebas dewasa ini, menuntut berkembangnya pola pikir konstruktif dan mempunyai daya saing global.

Dalam perspektif kurikulum 2013, tujuan pendidikan dapat dilihat untuk mengembangkan kecerdasan intelektual dan kecemerlangan akademik. Filosofi ini menentukan bahwa isi kurikulum adalah disiplin ilmu dan pembelajaran adalah pembelajaran disiplin ilmu (essentialism). Filosofi ini mewajibkan kurikulum memiliki nama matapelajaran yang sama dengan nama disiplin ilmu, selalu bertujuan untuk mengembangkan kemampuan intelektual dan kecemerlangan akademik. Pendidikan untuk membangun kehidupan masa kini dan masa depan yang lebih baik dari masa lalu dengan berbagai kemampuan intelektual, kemampuan berkomunikasi, sikap sosial, kepedulian, dan berpartisipasi untuk membangun kehidupan masyarakat dan bangsa yang lebih baik (experimentalism and social reconstructivism). Dengan filosofi ini, Kurikulum 2013 bermaksud untuk mengembangkan potensi peserta didik menjadi kemampuan dalam berpikir reflektif bagi penyelesaian masalah sosial

\footnotetext{
${ }^{4}$ Ma'as Shobirin, Konsep Implementasi Kurikulum 2013, (Yogyakarta: Deepublish, 2016), hlm. 26.
} 
di masyarakat, dan untuk membangun kehidupan masyarakat demokratis yang lebih baik. ${ }^{5}$

Dengan demikian, Kurikulum 2013 menggunakan filosofi sebagaimana di atas dalam mengembangkan kehidupan individu peserta didik dalam beragama, seni, kreativitas, berkomunikasi, nilai dan berbagai dimensi inteligensi yang sesuai dengan diri seorang peserta didik dan diperlukan masyarakat, bangsa dan ummat manusia.

\section{Materi dan Sumber Belajar}

Materi dalam kurikulum 2013 dijabarkan berdasarkan standar isi kurikulum 2013 yang diatur dalam Permendikbud nomor 64 tahun 2013. Dalam usaha mencapai Standar Kompetensi Lulusan sebagaimana telah ditetapkan untuk setiap satuan dan jenjang pendidikan, penguasaan kompetensi lulusan dikelompokkan menjadi beberapa Tingkat Kompetensi. Tingkat kompetensi menunjukkan tahapan yang harus dilalui untuk mencapai kompetensi lulusan yang telah ditetapkan dalam Standar Kompetensi Lulusan. Standar isi kurikulum 2013 untuk Madrasah Aliyah masuk kategori tingkat kompetensi 5 dan 6. Dalam tingkat kompetensi tersebut terdapat empat kompetensi yang harus dikuasai oleh peserta didik yang meliputi sikap spiritual, sikap sosial, pengetahuan, dan keterampilan. ${ }^{6}$

Table 1. Tingkat kompetensi 5 untuk kelas X dan XI SMA/MA

\begin{tabular}{|l|l|}
\hline KOMPETENSI & \multicolumn{1}{|c|}{ DESKRIPSI KOMPETENSI } \\
\hline Sikap Spiritual & $\begin{array}{l}\text { Menghayati dan mengamalkan ajaran agama yang } \\
\text { dianutnya }\end{array}$ \\
\hline
\end{tabular}

${ }^{5}$ Salinan Lampiran Peraturan Menteri Pendidikan dan Kebudayaan Nomor 59 Tahun 2014 Tentang Kerangka Dasar dan Struktur Kurikulum Sekolah Menengah Atas/Madrasah Aliyah, hlm. 4-5.

${ }^{6}$ Permendikbud Nomor 64 tahun 2013 tentang Standar Isi Pendidikan Dasar dan Menengah. 


\begin{tabular}{|c|c|}
\hline Sikap Sosial & $\begin{array}{l}\text { Menghayati dan mengamalkan perilaku jujur, } \\
\text { disiplin, tanggung jawab, peduli (gotong royong, } \\
\text { kerjasama, toleran, damai), santun, responsif dan } \\
\text { pro-aktif dan menunjukkan sikap sebagai bagian dari } \\
\text { solusi atas berbagai permasalahan dalam berinteraksi } \\
\text { secara efektif dengan lingkungan sosial dan alam } \\
\text { serta dalam menempatkan diri sebagai cerminan } \\
\text { bangsa dalam pergaulan dunia }\end{array}$ \\
\hline Pengetahuan & $\begin{array}{l}\text { Memahami, menerapkan, dan menganalisis } \\
\text { pengetahuan faktual, konseptual, prosedural, dan } \\
\text { metakognitif berdasarkan rasa ingin tahunya tentang } \\
\text { ilmu pengetahuan, teknologi, seni, budaya, dan } \\
\text { humaniora dengan wawasan kemanusiaan, } \\
\text { kebangsaan, kenegaraan, dan peradaban terkait } \\
\text { penyebab fenomena dan kejadian, serta menerapkan } \\
\text { pengetahuan prosedural pada bidang kajian yang } \\
\text { spesifik sesuai dengan bakat dan minatnya untuk } \\
\text { memecahkan masalah }\end{array}$ \\
\hline Keterampilan & $\begin{array}{l}\text { Mengolah, menalar, dan menyaji dalam ranah } \\
\text { konkret dan ranah abstrak terkait dengan } \\
\text { pengembangan dari yang dipelajarinya di sekolah } \\
\text { secara mandiri, bertindak secara efektif dan kreatif, } \\
\text { serta mampu menggunakan metoda sesuai dengan } \\
\text { kaidah keilmuan }\end{array}$ \\
\hline
\end{tabular}


Table 2. Tingkat kompetensi 6 untuk kelas XII SMA/MA

\begin{tabular}{|c|c|}
\hline KOMPETENSI & DESKRIPSI KOMPETENSI \\
\hline Sikap Spiritual & $\begin{array}{l}\text { Menghayati dan mengamalkan ajaran agama yang } \\
\text { dianutnya }\end{array}$ \\
\hline Sikap Sosial & $\begin{array}{l}\text { Menghayati dan mengamalkan perilaku jujur, disiplin, } \\
\text { tanggung jawab, peduli (gotong royong, kerjasama, } \\
\text { toleran, damai), santun, responsif dan pro-aktif dan } \\
\text { menunjukkan sikap sebagai bagian dari solusi atas } \\
\text { berbagai permasalahan dalam berinteraksi secara efektif } \\
\text { dengan lingkungan sosial dan alam serta dalam } \\
\text { menempatkan diri sebagai cerminan bangsa dalam } \\
\text { pergaulan dunia }\end{array}$ \\
\hline Pengetahuan & $\begin{array}{l}\text { Memahami, menerapkan, menganalisis dan } \\
\text { mengevaluasi pengetahuan faktual, konseptual, } \\
\text { prosedural, dan metakognitif berdasarkan rasa ingin } \\
\text { tahunya tentang ilmu pengetahuan, teknologi, seni, } \\
\text { budaya, dan humaniora dengan wawasan kemanusiaan, } \\
\text { kebangsaan, kenegaraan, dan peradaban terkait } \\
\text { penyebab fenomena dan kejadian, serta menerapkan } \\
\text { pengetahuan prosedural pada bidang kajian yang } \\
\text { spesifik sesuai dengan bakat dan minatnya untuk } \\
\text { memecahkan masalah }\end{array}$ \\
\hline Keterampilan & $\begin{array}{l}\text { Mengolah, menalar, menyaji, dan mencipta dalam ranah } \\
\text { konkret dan ranah abstrak terkait dengan pengembangan } \\
\text { dari yang dipelajarinya di sekolah secara mandiri serta } \\
\text { bertindak secara efektif dan kreatif, dan mampu } \\
\text { menggunakan metoda sesuai dengan kaidah keilmuan }\end{array}$ \\
\hline
\end{tabular}


Selanjutnya terkait dengan materi pelajaran, Badan Standar Nasional Pendidikan (BSNP) telah mengembangkan instrumen penilaian buku teks yang merupakan sumber utama materi pelajaran. Instrumen ini dipakai untuk menentukan kelayakan sebuah buku teks untuk dapat dikategorikan sebagai buku standar. Menurut BSNP yang dikutip dari Masnur Muslich, buku teks yang berkualitas wajib memenuhi empat unsur kelayakan, yaitu kelayakan isi, kelayakan penyajian, kelayakan kebahasaan, dan kelayakan kegrafikan. ${ }^{7}$

Bagian isi dalam buku ajar merupakan uraian materi tentang pokok bahasan yang sesuai dengan judul buku. Uraian materi harus dapat mengembangkan pengetahuan, keterampilan, dan sikap positif peserta didik. Untuk itu, dari segi materi, buku ajar yang baik harus memnuhi kriteria sebagai berikut:

a. Harus dapat menjaga kebenaran dan keakuratan materi, kemutakhiran data dan konsep, serta dapat mendukung pencapaian tujuan pendidikan nasional.

b. Menggunakan sumber materi yang benar secara teoritik dan empirik.

c. Mendorong timbulnya kemandirian dan inovasi.

d. Mampu memotivasi untuk mengembangkan dirinya.

e. Mampu menjaga persatuan dan kesatuan bangsa dengan mengakomodasi kebhinnekaan, sifat gotong royong, dan menghargai pelbagai perbedaan. ${ }^{8}$

Dari segi kelayakan penyajian materi, buku ajar yang baik setidaknya memenuhi kriteria sebagai berikut:

\footnotetext{
${ }^{7}$ Muslich, Masnur. Text Book Writing: Dasar-Dasar Pemahaman, Penulisan, dan Pemakaian Buku Teks. Ar-Ruzz Media. (Yogyakarta, 2010), hlm.291.

${ }^{8}$ Salinan Lampiran Peraturan Menteri Pendidikan dan Kebudayaan Nomor 8 Tahun 2016 Tentang Buku yang Digunakan oleh Satuan Pendidikan, hlm. 5.
} 
a. Materi buku disajikan secara menarik (runtut, koheren, lugas, mudah dipahami, dan interaktif), sehingga keutuhan makna yang ingin disampaikan dapat terjaga dengan baik.

b. Ilustrasi materi, baik teks maupun gambar menarik sesuai dengan tingkat perkembangan usia pembaca dan mampu memperjelas materi/konten serta santun.

c. Penggunaan ilustrasi untuk memperjelas materi tidak mengandung unsur pornografi, paham ekstrimisme, radikalisme, kekerasan, SARA, bias gender, dan tidak mengandung nilai penyimpangan lainnya.

d. Penyajian materi dapat merangsang untuk berpikir kritis, kreatif, dan inovatif.

e. Mengandung wawasan kontekstual, dalam arti relevan dengan kehidupan keseharian serta mampu mendorong pembaca untuk mengalami dan menemukan sendiri hal positif yang dapat diterapkan dalam kehidupan keseharian.

f. Penyajian materi menarik sehingga menyenangkan bagi pembacanya dan dapat menumbuhkan rasa keingintahuan yang mendalam. ${ }^{9}$

Kemudian dari segi kebahasaan, buku ajar yang baik setidaknya memenuhi kriteria sebagai berikut:

a. Penggunaan bahasa (ejaan, kata, kalimat, dan paragraf) tepat, lugas, jelas, serta sesuai dengan tingkat perkembangan usia.

b. Ilustrasi materi, baik teks maupun gambar sesuai dengan tingkat perkembangan usia pembaca dan mempu memperjelas materi/konten.

\footnotetext{
${ }^{9}$ Muslich, Textbook Writing...., hlm. 291.
} 
c. Bahasa yang digunakan komunikatif dan informatif sehingga pembaca mampu memahami pesan positif yang disampaikan, memiliki ciri edukatif, santun, etis, dan estetis sesuai dengan tingkat perkembangan usia.

d. Judul buku dan judul bagian-bagian materi/konten buku harmonis/selaras, menarik, mampu menarik minat untuk membaca, dan tidak provokatif. ${ }^{10}$

Selanjutnya dari segi aspek kegrafikan, buku ajar yang baik setidaknya memenuhi kriteria sebagai berikut:

a. Ukuran buku sesuai dengan tingkat perkembangan usia dan materi/konten buku.

b. Tampilan tata letak unsur kulit buku sesuai/harmonis dan memiliki kesatuan (unity).

c. Pemberian warna pada unsur tata letak harmonis dan dapat memperjelas fungsi.

d. Penggunaan huruf dan ukuran huruf disesuaikan dengan tingkat perkembangan usia.

e. Ilustrasi yang digunakan mampu memperjelas pesan yang ingin disampaikan. ${ }^{11}$

Selanjutnya, materi Bahasa Arab di Madrasah Aliyah harus memperhatikan empat kemahiran berbahasa (mahārah al-ta'bīr, mahārah alistimā', mahārah al-qirā'ah, dan mahārah al-kitābah). Secara umum butir instrumen penilaian buku teks pelajaran bahasa Arab Sekolah Menengah Atas (SMA)/Madrasah Aliyah (MA) mencakup kelayakan isi dan kelayakan penyajian. Dalam butir kelayakan isi meliputi enam butir indikator, yaitu kesesuaian uraian dengan materi dengan kompetensi inti (KI) dan kompetensi

\section{${ }^{10}$ Ibid. \\ ${ }^{11}$ Ibid.}


dasar (KD), keakuratan materi, kemutahiran materi, kesesuaian budaya, latihan dan evaluasi, serta pengayaan. Kemudian dalam butir kelayakan penyajian mencakup empat indikator, yaitu teknik penyajian, pendukung penyajian, strategi penyajian materi, serta koherensi dan keruntutan alur pikir. ${ }^{12}$

Dalam butir pendukung penyajian, buku ajar harus disajikan dengan dilengkapi materi audio untuk mendukung kemahiran istima $\bar{a}$. Materi audio disajikan sebagai sarana penunjang yang tidak terpisahkan dari isi buku, dengan ikon audio (gambar kaset/CD, dll) yang materinya dapat dituliskan dalam bab. Materi audio memberi motivasi dan solusi, baik bagi peserta didik maupun guru dalam mengatasi kesulitan belajar. Penyajian materi audio dapat membantu peserta didik mempelajari lafal bahasa Arab yang baik dan benar. ${ }^{13}$ Untuk itu, dalam buku teks bahasa Arab hendaknya dilihat konten materi sebagai berikut:

\section{a. Hiwār/Mufrādat}

Kemampuan berbicara sebagai salah satu tujuan pembelajaran bahasa bukan saja bagaimana seorang pembelajar dapat menguasai kosakata, akan tetapi yang lebih intens dari itu adalah kemampuaannya untuk mengaplikasikan kosakata tersebut dalam berbagai lapangan kehidupan. Dengan juga dengan pembelajaran bahasa arab, sudah barang tentu menuntut oleh keterampilan berbicara dan metode langsung tetap menjadi acuan pokok demi tercapainya tujuan yang diinginkan dari pembelajaran tersebut. ${ }^{14}$

Aspek ini merupakan jembatan/media dari para pembelajar dalam memperkaya penguasaan kosakata mereka untuk dapat lebih efektif dalam berkomunikasi. Dalam kaitannya dengan pemerolehan keterampilan

${ }^{12}$ Instrumen Penilaian 1 Buku Tekas Bahasa Arab SMA/MA BSNP Tahun 2014.

${ }^{13}$ Instrumen Penilaian 2 Buku Tekas Bahasa Arab SMA/MA BSNP Tahun 2014.

14 Yogia Prihartini, "Analisis Materi Keterampilan Berbicara Dalam Buku Ajar

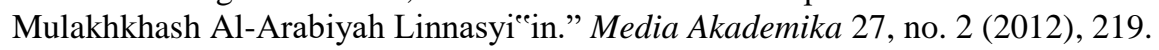


berbicara, maka kosakata yang ditampilkan dalam hiwar/ qira'ah adalah kosakata yang ada kaitannya dengan aktifitas sehari-hari pembelajar. Dan hal ini merupakan salah satu syarat atau ketentuan dalam pembelajaran keterampilan berbicara, sehingga tema yang dimuat berkisar apa yang dilihat dan dil akukan dilingkungannya.

\section{b. Qawaid}

Dalam kaitan ini dengan pembelajaran qawaid baik dari pola kalimat maupun persesuaian kata dalam kalimat merupakan hal yang bersifat mendasar, seperti persesuaian antara kata dengan kata yang lain dalam bahasa arab adalah kesesuaian antara $f i$ 'il (prediket) dengan $f \bar{a}^{\prime} i l$ (subyeknya), antara mubtadā' (subyek) dengan khabar (prediketnya). Antara sifat dengan mashufnya, antara athaf dengan mathuf-nya, baik dari segi mużakar (maskulin) ataupun muannas (feminim) dan dari segi mufrād (tunggal), muśanna (dual) dan jamak (floral). Sementara dalam bahasa Indonesia, system seperti ini tidak dikenal lagi. ${ }^{15}$ Hal ini diakui menjadi salah satu problema bagi pembelajar Indonesia dalam mempelajari bahasa arab.

\section{c. Tathbiq/Latihan}

Aspek ini merupakan alat pengukur sampai dimana para pembelajar dapat menguasai bahan yang disampaikan, terutama dalam kaitannya dengan keterampilan berbicara. Maka dalam hal ini erat hubungannya dengan sampai diaman para pembelajar dapat untuk mengaplikasikan kosakata yang telah dipelajari dan didapat. ${ }^{16}$

Untuk itu seharusnya lebih banyak diarahkan kepada latihan percakapan, pertanyaan menggali, bercerita, mendemonstrasikan gambar dan sebagainya. Sehingga kesempatan untuk mengunakan bahasa arab langsung lebih banyak dilalui para mahasiswa dari pada menulis.

\footnotetext{
${ }^{15}$ Ibid., hlm. 215.

${ }^{16}$ Ibid.
} 


\section{Strategi dan Metode Pembelajaran}

Teori pendidikan yang melandasi pengembangan kurikulum terdapat perbedaan dalam menentukan tujuan dan materi pembelajaran, hal ini tentunya memiliki konsekuensi pula terhadap strtegi pembelajaran yang hendak dikembangkan. Apabila yang menjadi tujuan dalam pembelajaran adalah penguasaan informasi intelektual, maka strategi pembelajaran yang dikembangkan akan lebih berpusat kepada guru. Guru merupakan tokoh sentral di dalam proses pembelajaran dan dipandang sebagi pusat informasi dari guru. Metode dan tekhnik pembelajaran yang digunakan pada umumnya bersifat penyajian (eksposiotarik) secara missal, seperti ceramah atau seminar. Selain itu, pembelajaran lebih cendrung bersifat tekstual.

Namun beberapa kalangan menilai bahwa yang seharusnya aktif dalam suatu proses pembelajaran peserta didik itu sendiri. Peserta didik secara aktif menentukan materi dan tujuan belajarnya sesuai dengan minat dan kebutuhannya. Sekaligus menentukan bagaimana cara-cara yang paling sesuai untuk memperoleh materi dan mencapai tujuan belajarnya. Pembelajaran cenderung bersifat kontekstual. Metode dan teknik pembelajaran yang digunakan tidak lagi dalam bentuk penyajian dari guru tetapi lebih bersifat individual, langsung dan memanfaatkan proses dinamika kelompok (kooperatif), seperti pembelajaran observasi, simulasi, atau role play, diskusi, dan sejenisnya. ${ }^{17}$

Dalam hal ini, guru tidak banyak melakukan intervensi peran guru hanya sebagai fasilitator, motivator dan guider. Sebagai fasilitator, guru berusaha menciptakan dan menyediakan lingkungan belajar yang kondusif bagi peserta didiknya. Sebagai motivator, guru berupaya mendorong dan menstimulasi peserta didiknya agar dapat melakukan perbuatan belajar.

\footnotetext{
${ }^{17}$ Ibid, hlm. 27.
} 
Sedangkan sebagai guider, guru melakukan pembimbingan dengan berusaha mengenal peserta didiknya secara personal.

Kurikulum 2013 mengetengahkan strategi pembelajaran yang berbeda dibanding kurikulum sebelumnya. Pola pembelajaran yang berpusat pada guru menjadi pembelajaran berpusat pada peserta didik. Peserta didik harus memiliki pilihan-pilihan terhadap materi yang dipelajari untuk memiliki kompetensi yang sama. Pembelajaran konvensional yang cenderung satu arah (interaksi guru-peserta didik) menjadi pembelajaran interaktif (interaktif gurupeserta didik-masyarakat-lingkungan alam, sumber/media lainnya). Selain itu, pola pembelajaran terisolasi menjadi pembelajaran secara jejaring, pola pembelajaran pasif menjadi pembelajaran aktif dengan model pembelajaran pendekatan sains, dan pola belajar sendiri menjadi belajar kelompok (berbasis tim). ${ }^{18}$

Kegiatan pembelajaran merupakan proses pendidikan yang memberikan kesempatan kepada siswa untuk mengembangakan potensi mereka menjadi kemampuan yang semakin meningkat dalam sikap, pengetahuan, dam keterampilan yang diperlukan dirinya untuk hidup dan bermasyarakat, berbangsa, serta berkontribusi pada kesejahteraan hidup umat manusia.oleh karena itu, kegiatan pembelajaran diarahkan untuk memberdayakan semua potensi siswa menjadi kompetensi yang diharapkan. Lebih lanjut, strategi pembelajaran harus diarahkan untuk memfasilitasi pencapaian kompetensi yang telah dirancang dalam dokumen kurikulum agar setiap individu mampu menjadi pembelajar mandiri sepanjang hayat, dan pada gilirannya mereka menjadi komponen penting untuk mewujudkan masyarakat belajar.

${ }^{18}$ Salinan Lampiran Peraturan Menteri Pendidikan dan Kebudayaan Nomor 59 Tahun 2014 Tentang Kerangka Dasar dan Struktur Kurikulum Sekolah Menengah Atas/Madrasah Aliyah, hlm. 2. 
Kualitas lain yang dikembangkan kurikulum dan harus terealisasikan dalam proses pembelajaran, antara lain: kreativitas, kemandirian, kerja sama, solidaritas, kepemimpinan, empati, toleransi dan kecakapan hidup siswa guna membentuk watak, serta meningkatkan peradaban dan martabat bangsa. Untuk mencapai kualitas yang telah dirancang dalam dokumen kurikulum, kegiatan pembelajaran perlu menggunakan prinsip sebagai berikut :

a). Berpusat pada siswa

b). Mengembangkan kreativitas siswa

c). Menciptakan kondisi menyenangkan dan menantang.

d). Bermuatan nilai, etika, estetika, logika, dan kinenstetika, dan

e). Menyediakan pengalaman belajar yang beragam melalui penerapan berbagai strategi dan metode pembelajaran yang menyenangkan, kontekstual, efektif, efesien, dan bermakna. ${ }^{19}$

Dalam Permendikbud Nomor 59 tahun 2014, ada beberapa model pembelajaran yang dapat digunakan dalam implementasi kurikulum 2013. Di antaranya:

\section{a. Model Pembelajaran Langsung}

Direct Instruction diartikan dengan Instruksi Langsung dikenal juga dengan active learning atau ada juga yang menamakan whole-class teaching. Hal ini mengacu pada gaya mengajar guru yang mengusung isi pelajaran kepada peserta didik dan mengajarkannya secara langsung kepada mereka. Karena model ini masih merupakan rentetan dari model pembelajaran behavioral, maka sasaran yang dilakukan oleh guru adalah pencapaian tingkah laku yang lebih positif dan lebih baik dari sebelumnya, kepada seluruh peserta didik Dalam model ini juga, guru menjelaskan mengenai suatu konsep baru kepada peserta didik. Pembelajarannya ditekankan pada aspek modelling,

\footnotetext{
${ }^{19}$ Shobirin, Konsep Implementasi..., hlm. 28.
} 
reinforcement (penguatan), feedback (respon balik), successive approximation (perkiraan suksesif), yang pada akhirnya tercipta tingkah laku peserta didik yang lebih positif. Oleh karena karakternya yang seperti itu, tidak semua materi dapat menggunakan model ini, model ini hanya dapat diterapkan pada materimateri yang membutuhkan latihan, meskipun demikian model ini mempunyai track record empiris yang cukup solid. ${ }^{20}$

Dalam pembelajaran langsung tersebut siswa melakukan kegiatan belajar mengamati, menanya, mengumpulkan informasi,mengasosiasi atau menganalisis, dan mengomunikasikan apa yang sudah ditemukannya dalam kegiatan analisis. Proses pembelajaran langsung menghasilkan pengetahuan dan keterampilan langsung atau yang disebut dengan instructional effect. ${ }^{21}$

\section{b. Model Pembelajaran Kooperatif}

Cooperative learning mencakup suatu kelompok kecil siswa yang bekerja sebagai sebuah tim untuk menyelesaikan sebuah masalah, menyelesakan suatu tugas, atau untuk mengerjakan sesuatu untuk mencapai tujuan bersama lainnya. Bukanlah cooperative learning jika siswa duduk bersama dalam kelompok-kelompok kecil dan mempersilahkan salah seorang diantaranya untuk menyelesaikan pekerjaan seluruh kelompok.

Cooperative learning menekankan pada kehadiran teman sebaya yang berinteraksi antar sesamanya sebagai sebuah tim dalam menyelesaikan atau membahas suatu masalah atau tugas. Ada beberapa hal yang perlu dipenuhi dalam cooperative learning agar lebih menjamin para siswa bekerja secara kooperatif, hal tersebut meliputi: pertama para siswa yang tergabung dalam suatu kelompok harus merasa bahwa mereka adalah bagian dari sebuah tim dan mempunyai tujuan bersama yang harus dicapai. Kedua para siswa yang

${ }^{20}$ Salinan Lampiran III Peraturan Menteri Pendidian dan Kebudayaan Nomor 59 tahun 2014 tentang Kurkulum 2013 Sekolah Menengah Atas/Madrasah Aliyah, hlm. 11.

${ }^{21}$ Rusman, Belajar dan Pembelajaran: Berorientasi Standar Proses Pendidikan, (Bandung:Kencana, 2017), hlm. 10. 
tergabung dalam sebuah kelompok harus menyadari bahwa masalah yang mereka hadapi adalah masalah kelompok dan bahwa berhasil atau tidaknya kelompok itu akan menjadi tanggung jawab bersama oleh seluruh anggota kelompok itu. Ketiga untuk mencapai hasil yang maksimum, para siswa yang tergabung dalam kelompok itu harus berbicara satu sama lain dalam mendiskusikan masalah yang dihadapinya. Pembelajaran kooperatif dapat didefinisikan sebagai sistem kerja/belajar kelompok yangn terstruktur. Yang termasuk di dalam struktur ini adalah lima unsur pokok, yaitu saling ketergantungan positis, tanggung jawab individual, interaksi personal, keahlian bekerja sama, dan proses kelompok. ${ }^{22}$

\section{c. Model Pembelajaran Kontekstual}

Pembelajaran kontekstual merupakan konsep belajar yang dapat membantu guru mengaitkan antara materi yang diajarkannya dengan situasi dunia nyata siswa dan mendorong siswa membuat hubungan antara pengetahuan yang dimilikinya dengan penerapannya dalam kehidupan mereka sebagai anggota keluarga dan masyarakat. Untuk memperkuat pengalaman belajar siswa diperlukan pembelajaran yang lebih banyak memberikan kesempatan kepada siswa untuk melakukan, mencoba, dan mengalami sendiri, dan bahkan sekedar sebagai pendengar yang pasif sebagaimana penerima terhadap semua informasi yang disampaikan guru. ${ }^{23}$ Oleh karena itu melalui pendekatan CTL, mengajar bukan transformasi pengetahuan dari guru kepada sisawa dengan menghafal sejumlah konsep-konsep yang sepertinya terlepas dari kehidupan nyata, akan tetapi lebih ditekankan pada upaya memfasilitasi siswa untuk mencari kemampuan untuk bisa hidup dari apa yang dipelajarinya.

22 Salinan Lampiran III Peraturan Menteri Pendidian dan Kebudayaan Nomor 59 tahun 2014 tentang Kurkulum 2013 Sekolah Menengah Atas/Madrasah Aliyah, hlm. 12.

${ }^{23}$ Ibid. 
Karena pada dasarnya pembelajaran kontekstual adalah konsep belajar dimana guru menghadirkan dunia nyata kedalam kelas dan mendorong siswa membuat hubungan antara pengetahuan yang dimilikinya dengan penerapannya dalam kehidupan mereka sehari-hari, sementara siswa memperoleh pengetahuan dan ketrampilan dari konteks yang terbatas, sedikit demi sedikit, dan dari proses mengkonstruksi sendiri, sebagai bekal untuk memecahkan masalah dalam kehidupannya sebagai anggota masyarakat. Oleh karena itu, dalam proses pembelajaran kurikulum 2013, semua kegiatan yang terjadi selama belajar di sekolah dan di luar dalam kegiatan kokurikuler dan ekstrakurikuler terjadi proses pembelajaran untuk mengembangkan moral dan prilaku yang terkait dengan sikap. Baik pembelajaran langsung maupun pembelajaran tidak langsung terjadi secara terintegrasi dan tidak terpisah.

\section{Media Pembelajaran Sebagai Alat Penunjang Pembelajaran}

Kata media berasal dari bahasa latin yang merupakan bentuk jamak dari kata medium. Secara bahasa memiliki arti perantara atau pengantar. Sedangkan secara istilah media pembelajaran adalah segala sesuatu yang dapat digunakan untuk menyalurkan pesan dari pengirim ke penerima sehingga dapat merangsang pikiran, perasaan, perhatian, dan minat serta perhatian siswa, sehingga proses pembelajaran dapat berlangsung dengan optimal. $^{24}$

Media adalah komponen sumber belajar atau wahana fisik yang mengandung materi instruksional dilingkungan siswa yang dapat merangsang siswa untuk belajar. Adapun media pembelajaran adalah media yang membawa pesan-pesan atau informasi yang bertujuan instruksional atau yang mengandung maksud-maksud pengajaran. ${ }^{25}$ hlm. 6-7

${ }^{24}$ Arif Sadiman, dkk. Media Pendidikan, (Jakarta: Raja Grafindo Persada, 2012),

${ }^{25}$ Hamdani, Strategi Belajar Mengajar, (Bandung, Pustaka Setia, 2011), hlm. 243 
Menurut Sanaky media audio visual adalah seperangkat alat yang dapat memproyeksikan gambar dan suara. Alat-alat yang termasuk media audio visual contohnya televisi, video-VCD, sound slide, dan film. ${ }^{26}$ Media audio visual merupakan perpaduan yang saling mendukung antara gambar dan suara, yang mampu menggugah perasaan dan pemikiran bagi yang menonton. Contoh media audio visual adalah sound slide, televisi, film, dan sebagainya. Media audio visual terdiri dari software yaitu bahan-bahan informasi yang terdapat dalam sound slide, kaset televisi, film, dan hardware yaitu segenap peralatan teknis yang memungkinkan software bisa dinikmati contohnya tape, proyektor, slide, dan proyektor film.

Kurikulum 2013 memadukan media pembelajaran inovatif. Berdasarkan salinan Permendikbud nomor 59 tahun 2014, Media pembelajaran adalah segala sesuatu yang dapat menyalurkan pesan, dapat merangsang fikiran, perasaan, dan kemauan peserta didik sehingga dapat mendorong terciptanya proses belajar pada diri peserta didik. Media pembelajaran berfungsi sebagai alat bantu guru untuk mengajar yang berupa alat bantu audio-visual, komputer internet dan lain sebagainya. ${ }^{27}$

Macam-macam media belajar Pendidikan Agama Islam, diantaranya:

a. Media Visual: grafik, diagram, chart, bagan, poster, kartun, komik

b. Media Audial : radio, tape recorder, laboratorium bahasa, dan sejenisnya

c. Projected still media : slide; over head projektor (OHP), in focus dan sejenisnya. hlm. 45

${ }^{26}$ Sanaky, Hujair.. Media Pembelajaran. (Yogyakarta: Safiria Insania Press, 2009),

27 Salinan Lampiran Peraturan Menteri Pendidikan dan Kebudayaan Nomor 59 Tahun 2014 Tentang Kerangka Dasar dan Struktur Kurikulum Sekolah Menengah Atas/Madrasah Aliyah, hlm. 22. 
d. Projected motion media : film, televisi, video (VCD, DVD, VTR), komputer dan sejenisnya.

e. Sejalan dengan perkembangan IPTEK penggunaan media, baik yang bersifat visual, audial, projected still media maupun projected motion media bisa dilakukan secara bersama dan serempak melalui satu alat saja yang disebut Multi Media. Sebagai contoh dalam penggunaan komputer tidak hanya bersifat projected motion media, namun dapat meramu semua jenis media yang bersifat interaktif. ${ }^{28}$

Ada beberapa kriteria yang perlu diperhatikan dalam pemilihan media antara lain:

a. Dalam pemilihan media harus sesuai dengan tujuan pembelajaran, dan kompetensi yang ingin dicapai.

b. Media yang akan digunakan harus disesuaikan dengan materi pembelajaran.

c. Media harus disesuaikan dengan karakteristik siswa/guru. Karakteristik siswa dilihat dari segi kuantitatif ataupun kualitatif terhadap media yang akan digunakan. Artinya ada media yang cocok untuk sekelompok siswa, namun tidak cocok dengan siswa lainnya. Misalnya ada siswa yang memiliki kekurangan pada salah satu alat inderanya, maka guru tidak akan memilih media yang tidak bisa diserap oleh indera peserta didiknya.

d. Media yang dipilih bukan karena fanatisme guru terhadap suatu media yang dianggap paling disukai dan paling bagus, namun didasarkan atas teori yang diangkat dari penelitian dan riset sehingga teruji validitasnya. Media yang dipilih harus menunjukkan efisiensi dan efektivitas pembelajaran.

\section{${ }^{28}$ Ibid.}


e. Kesesuaian dengan gaya belajar siswa. Siswa yang belajar dipengaruhi oleh gaya belajar, oleh karenanya pemilihan media harus didasarkan pada kondisi psikologis siswa. ${ }^{29}$

\section{Evaluasi Sebagai Instrumen Pengukur Hasil Pembelajaran}

Berbagai metode dan instrument baik formal maupun nonformal di gunakan dalam penilain untuk mengumpulkan informasi. Informasi yang dikumpulkan menyangkut semua perubahan yang terjadi baik secara kualitatif maupun kuantitatif. Penilaian dapat dilakukan selama pembelajaran berlangsung (penilain proses) dan setelah pembelajaran usai dilaksanakan (penilaiain hasil/produk). Penilaian informasi bisa berupa komentar-komentar guru yang diberikan/diucapkan selama proses pembelajaran. Saat seseorang peserta didik menjawab pertanyaan guru, saat seseorang peserta didik menjawab pertanyaan guru, saat seseorang peserta didik atau beberapa peserta didik mengajukan pertanyaan kepada guru atau temannya.

Dalam kurikulum 2013 terdapat tiga komponen penilaian, yaitu penilaian sikap spiritual dan sosial, penilaian pengetahuan, dan penilaian keterampilan.

\section{a. Penilaian Sikap Spiritual dan Sosial}

Penilaian sikap adalah penilaian terhadap kecenderungan perilaku peserta didik sebagai hasil pendidikan, baik di dalam kelas maupun di luar kelas. Penilaian sikap memiliki karakteristik yang berbeda dengan penilaian pengetahuan dan keterampilan, sehingga teknik penilaian yang digunakan juga berbeda. Dalam hal ini, penilaian sikap ditujukan untuk mengetahui capaian dan membina perilaku serta budi pekerti peserta didik sesuai butirbutir sikap dalam Kompetensi Dasar (KD) pada Kompetensi Inti Sikap Spiritual (KI-1) dan Kompetensi Inti Sikap Sosial (KI-2). Penilaian sikap

\section{${ }^{29}$ Ibid.}


spiritual dan sikap sosial dilakukan secara berkelanjutan oleh pendidik mata pelajaran, guru Bimbingan Konseling (BK), dan wali kelas dengan menggunakan observasi dan informasi lain yang valid dan relevan dari berbagai sumber. Penilaian sikap merupakan bagian dari pembinaan dan penanaman/pembentukan sikap spiritual dan sikap sosial peserta didik yang menjadi tugas dari setiap pendidik. ${ }^{30}$

\section{b. Penilaian Pengetahuan}

Penilaian pengetahuan merupakan penilaian untuk mengukur kemampuan peserta didik berupa pengetahuan faktual, konseptual, prosedural, dan metakognitif, serta kecakapan berpikir tingkat rendah sampai tinggi. Penilaian ini berkaitan dengan ketercapaian Kompetensi Dasar pada KI-3 yang dilakukan oleh guru mata pelajaran. Penilaian pengetahuan dilakukan dengan berbagai teknik penilaian. Pendidik menetapkan teknik penilaian sesuai dengan karakteristik kompetensi yang akan dinilai. Penilaian dimulai dengan perencanaan pada saat menyusun Rencana Pelaksanaan Pembelajaran (RPP) dengan mengacu pada silabus. Penilaian pengetahuan, selain untuk mengetahui apakah peserta didik telah mencapai ketuntasan belajar, juga untuk mengidentifikasi kelemahan dan kekuatan penguasaan pengetahuan peserta didik dalam proses pembelajaran (diagnostic). ${ }^{31}$ Oleh karena itu, pemberian umpan balik (feedback) kepada peserta didik oleh pendidik merupakan hal yang sangat penting, sehingga hasil penilaian dapat segera digunakan untuk perbaikan mutu pembelajaran. Ketuntasan belajar untuk pengetahuan ditentukan oleh satuan pendidikan dengan mempertimbangkan batas standar minimal nilai Ujian Nasional yang ditetapkan oleh Pemerintah.

${ }^{30}$ Kemendikbud, Panduan Penilaian Kurikulum 2013 untuk Sekolah Menengah Atas, (Jakarta: Kemendikbud, 2015), hlm. 7.

${ }^{31}$ Ibid., hlm. 8. 


\section{c. Penilaian Keterampilan}

Penilaian keterampilan adalah penilaian untuk mengukur pencapaian kompetensi peserta didik terhadap kompetensi dasar pada KI-4. Penilaian keterampilan menuntut peserta didik mendemonstrasikan suatu kompetensi tertentu. Penilaian ini dimaksudkan untuk mengetahui apakah pengetahuan yang sudah dikuasai peserta didik dapat digunakan untuk mengenal dan menyelesaikan masalah dalam kehidupan sesungguhnya (real life). Ketuntasan belajar untuk keterampilan ditentukan oleh satuan pendidikan, secara bertahap satuan pendidikan terus meningkatkan kriteria ketuntasan belajar dengan mempertimbangkan potensi dan karakteristik masing-masing satuan pendidikan sebagai bentuk peningkatan kualitas hasil belajar. ${ }^{32}$

\section{d. Karakteristik Penilaian}

1) Belajar Tuntas

Untuk kompetensi pada kategori pengetahuan dan keterampilan (KI-3 dan KI-4). Peserta didik tidak diperkenankan mengejarkan pekerjaan berikutnya. Sebelum mampu menyelesaikan pekerjaan dengan prosedur yang benar dan hasil yang baik. Asumsi yang digunakan dalam belajar tuntas adalah peserta didik dapat belajar lambat perlu waktu lebih lama untuk materi yang sama, dibandingkan peserta didik pada umumnya.

2) Autentik,

Memandang penilaian dan pembelajaran secara terpadu. Penilaian autentik harus mencerminkan masalah dunia nyata, bukan sekolah. Menggunakan berbagai cara dan criteria holistic ( kompetensi utuh mereflesikan pengetahuan, keterampilan, dan sikap). Penilaian autentik tidak hanya mengukur apa yang diketahui oleh peserta didik, tetapi

\footnotetext{
${ }^{32}$ Ibid., hlm. 9.
} 
lebih menekankan mengukur apa yang dapat dilakukan oleh peserta didik.

3) Berkesinambungan

Tujuannya adalah untuk mendapatkan gambaran yang utuh mengenai perkembangan hasil belajar peserta didik, memantau proses, kemajuan, dan perbaikan hasil terus menerus dalam bentuk penilaian proses, dan berbagai jenis ulangan secara berkelanjutan (ulangan harian, ulangan tengah semester, ulangan akhir semester, atau ulangan kenaikan kelas).

\section{Simpulan}

Secara praksis, kurikulum dapat dipahami sebagai blue print tindakantindakan yang meliputi tujuan, isi, kebutuhan peserta didik, kegiatan belajar, proses instruksional dan sumber daya, serta metode penilaian dan evaluasi. Diskursus tersebut sangat dipengaruhi oleh pijakan epistemologisfilosofis kerangka bangun keilmuan yang digunakan. Untuk itu, pembelajaran bahasa Arab di Madrasah Aliyah hendaknya memperhatikan komponenkomponen kurikulum, seperti tujuan pembelajaran, Materi dan sumber belajar, strategi dan metode pembelajaran, dan evaluasi sebagai instrumen penilaian. 


\section{DAFTAR PUSTAKA}

Hamdani, Strategi Belajar Mengajar, Bandung, Pustaka Setia, 2011.

Hujair, Sanaky, Media Pembelajaran. Yogyakarta: Safiria Insania Press, 2009.

Instrumen Penilaian 1 Buku Tekas Bahasa Arab SMA/MA BSNP Tahun 2014. Instrumen Penilaian 2 Buku Tekas Bahasa Arab SMA/MA BSNP Tahun 2014. Kemendikbud, Panduan Penilaian Kurikulum 2013 untuk Sekolah Menengah Atas, Jakarta: Kemendikbud, 2015.

Muslich, Masnur. Text Book Writing: Dasar-Dasar Pemahaman, Penulisan, Dan Pemakaian Buku Teks. Ar-Ruzz Media. Yogyakarta, 2010.

Permendikbud Nomor 64 tahun 2013 tentang Standar Isi Pendidikan Dasar dan Menengah.

Prihartini, Yogia. "Analisis Materi Keterampilan Berbicara Dalam Buku Ajar Mulakhkhash Al-Arabiyah Linnasyi" in." Media Akademika 27, no. 2 (2012)

Ross, Wayne, The Social Studies Curriculum: Purposes, Problems, and Possibilities, New York: State University of New York Press, 2008.

Rusman, Belajar dan Pembelajaran: Berorientasi Standar Proses Pendidikan, Bandung:Kencana, 2017.

Sadiman, Arif, dkk. Media Pendidikan, Jakarta: Raja Grafindo Persada, 2012. Salinan Lampiran III Peraturan Menteri Pendidian dan Kebudayaan Nomor 59 tahun 2014 tentang Kurkulum 2013 Sekolah Menengah Atas/Madrasah Aliyah.

Salinan Lampiran Peraturan Menteri Pendidikan dan Kebudayaan Nomor 59

Tahun 2014 Tentang Kerangka Dasar dan Struktur Kurikulum Sekolah Menengah Atas/Madrasah Aliyah.

Salinan Lampiran Peraturan Menteri Pendidikan dan Kebudayaan Nomor 8 Tahun 2016 Tentang Buku yang Digunakan oleh Satuan Pendidikan.

Sobirin, Ma'as, Konsep Implementasi Kurikulum 2013, Yogyakarta: Deepublish, 2016.

Syaodih, Nana, Metode Penelitian Pendidikan, Bandung: Rosdakarya, 2009.

Undang-undang Nomor 20 Tahun 2003 Tentang Sistem Pendidikan Nasional 